\title{
Assessment of some physicochemical parameters of rice and wheat varieties consumed in Mauritania
}

\author{
Mohamed MOUTALY*, Yacoub BAMBA and Mohamed ABDALLAHI BOLLAHI \\ Laboratoire de Contrôle de la Qualité des Eaux et Aliments, Institut National de Recherches en Santé \\ Publique, BP 695, Nouakchott, Mauritanie. \\ *Corresponding author; E-mail:mohamedmoutaly219@yahoo.com, mbeddou318@gmial.com
}

\begin{abstract}
The aim of this study was to evaluate the physicochemical parameters of rice and wheat varieties consumed in Mauritania. In this study, a total of six rice and three wheat varieties were analyzed for their physicochemical quality including moisture, protein, mineral contents and heavy metals. The result showed that Super rice had the highest moisture $(8.66 \%)$ and protein $(6.78 \%)$ content. The moisture content of the wheat varieties ranged between 5.56 to $7.07 \%$. Wheat variety Rosso $(7.98 \%)$ followed by Echeilal $(7.55 \%)$ showed more protein content than imported wheat variety. We can notice that the mineral content of the six rice varieties can be classified as follows: Zenkaloni> Basmati> Super> Local > Royal > Yebreg, while the mineral content of the three wheat varieties can be classified as follows: Echeilal > Imported> Rosso. The moisture, the protein, the minerals and heavy metals were all within acceptable levels.
\end{abstract}

(C) 2019 International Formulae Group. All rights reserved.

Keywords: Physicochemical, rice, wheat, protein, Nouakchott, Mauritania.

\section{INTRODUCTION}

Rice (Oryza sativa) and Wheat (Triticum aestivum L.) are two cereal grains that play a very important dietary role in the nutrition of human beings than other cereals (Yadav et al., 2007; Uthayakumaran and Wigley, 2010). Globally, over 2.58 billion tons of cereal grains such as wheat and rice (FAOSTAT, 2017) are produced annually and these cereal grains are stored for the purpose of food security and sustainability. The consumption of whole grain products has been linked to the reduced risk of chronic diseases (Mourouti et al., 2016).

In Mauritania, rice and wheat are the most important foods in the form of various products. However, with the opening of the border, many types of rice and wheat were found in all Mauritanian markets without quality control. In addition, we find the increasing of the local production in rice and wheat.

It is in this context that we are interested in studying these two important cereals. This work falls within this framework and concerns the identification of some physical and chemical characteristics of rice and wheat varieties consumed in Mauritania.

\section{MATERIALS AND METHODS Sampling}

One local variety and five varieties of rice imported where purchased from five different local markets in Wilaya of 
Nouakchott. The markets are Moughataa of Arafat, Riyadh, El Mina, Tevragh Zeina and Teyarett. The six rice varieties are: local, Yebreg, Super, Royal, Zenkaloni and Basmati. Two local varieties of wheat (type Rosso and type Echeilal) and one variety type imported where purchased from three different local markets. The markets are Moughataa of El Mina, Tevragh Zeina and Teyarett in Nouakchott. This is a prospective and descriptive study conducted in a period of three months between August and October 2015.

\section{Analytical methods}

The samples collected were analyzed for the following physicochemical characteristics, such as moisture, proteins, sodium (Na), Potassium (K), Calcium (Ca), Magnesium $(\mathrm{Mg})$, Iron $(\mathrm{Fe})$, Lead $(\mathrm{Pb})$ and Cadmium (Cd). The analyses were conducted at the Chemistry Laboratory at the National Institute of Public Health Research in Nouakchott, Mauritania. The moisture content of the corn samples was determined according to the ISO 712-1998 method "Determination of the water content at $110{ }^{\circ} \mathrm{C}$ ". The microKjeldahl method was employed to determine the total nitrogen and the crude protein $(\mathrm{N} \mathrm{x}$ 5.92). Levels of $\mathrm{Na}$ and $\mathrm{K}$ in corn samples were determined by flame emission photometry FP 640 type after the samples were digested with nitric acid $\left(\mathrm{HNO}_{3} 69 \%\right.$ sigma Aldrich) - hydrogen peroxide $\left(\mathrm{H}_{2} \mathrm{O}_{2}\right.$ sigma Aldrich). Levels of $\mathrm{Pb}, \mathrm{Cd}, \mathrm{Fe}$ and $\mathrm{Ca}$ in the corn samples were determined by Atomic Absorption Spectrophotometer (Thermo Scientific icE 3000) after digestion with concentrated $\mathrm{HNO}_{3}-\mathrm{H}_{2} \mathrm{O}_{2}$. Data were analyzed using analysis of Excel to detect any difference in mean values from triplicate.

\section{RESULTS}

Figures 1 and 2 show the distribution of moisture in rice and wheat varieties, respectively. Figures 3 and 4 show the distribution of protein in rice and wheat varieties, respectively. The minerals composition values of some rice and wheat varieties are presented in Table 1 . The Lead $(\mathrm{Pb})$ and cadmium $(\mathrm{Cd})$ values of some rice and wheat varieties are presented in Table 2 .

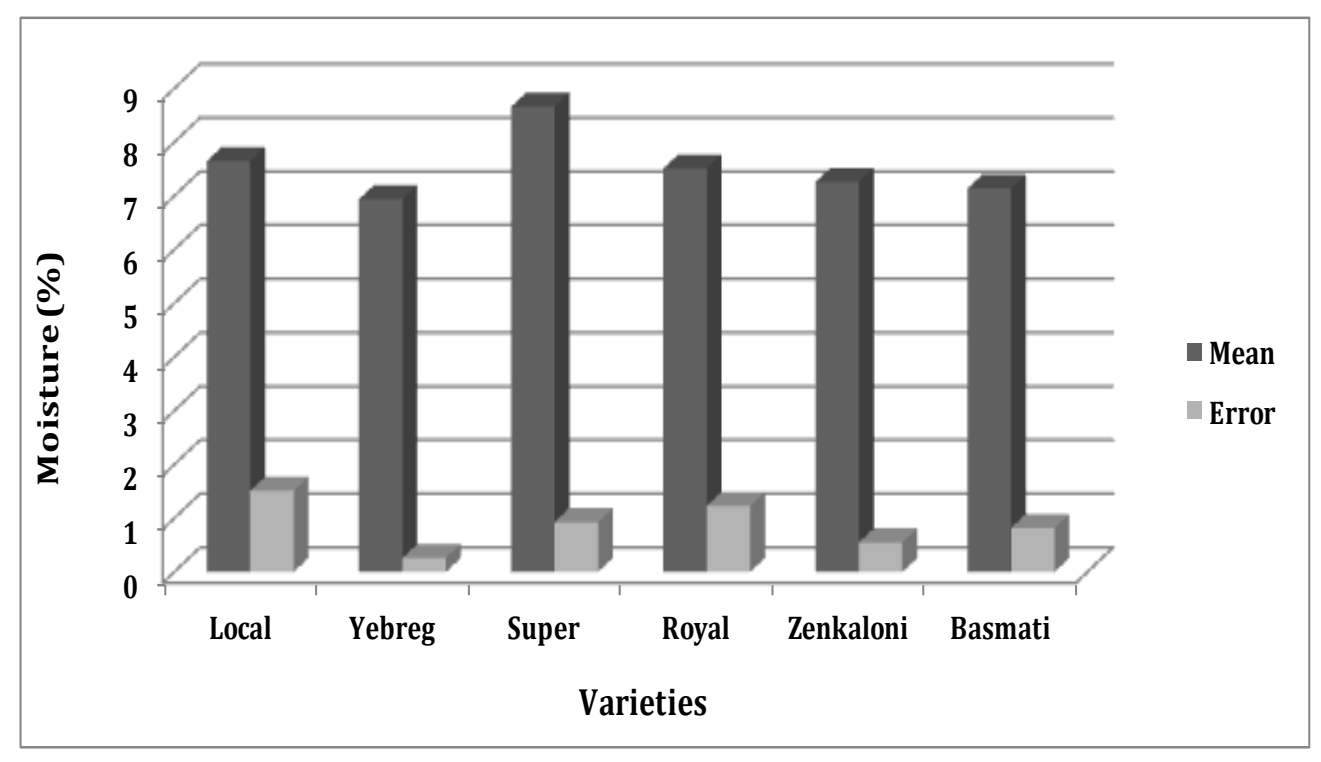

Figure 1: Distribution of moisture in rice varieties. 


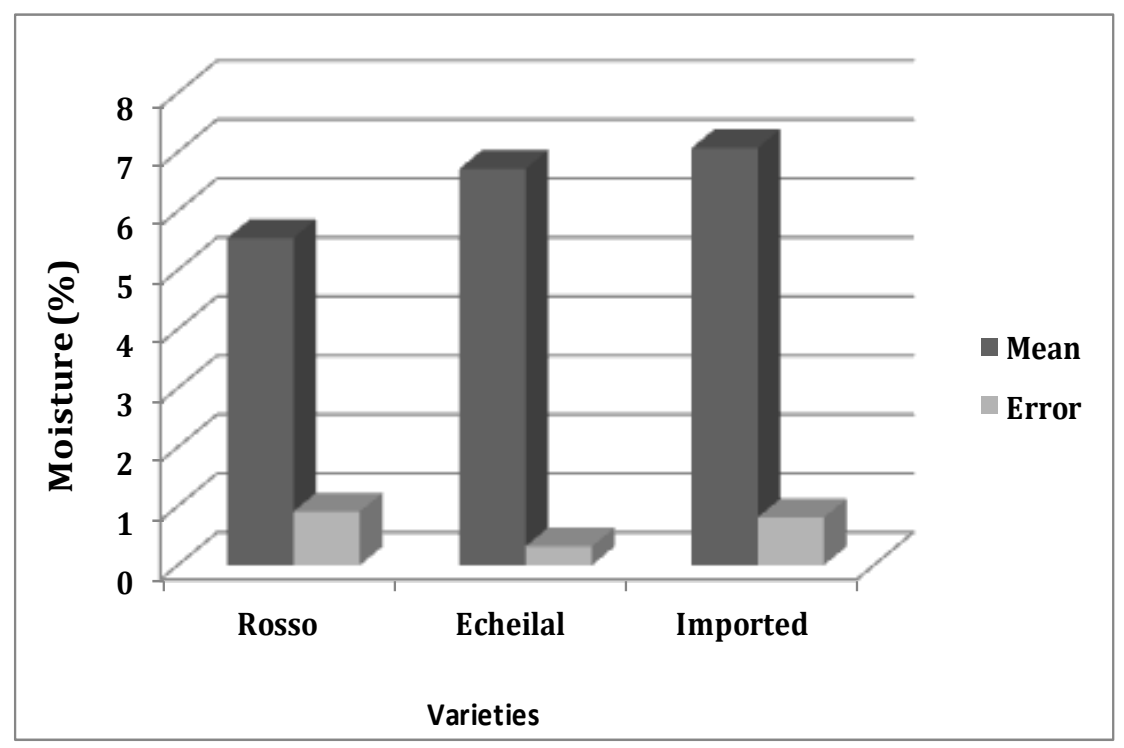

Figure 2: Distribution of moisture in wheat varieties.

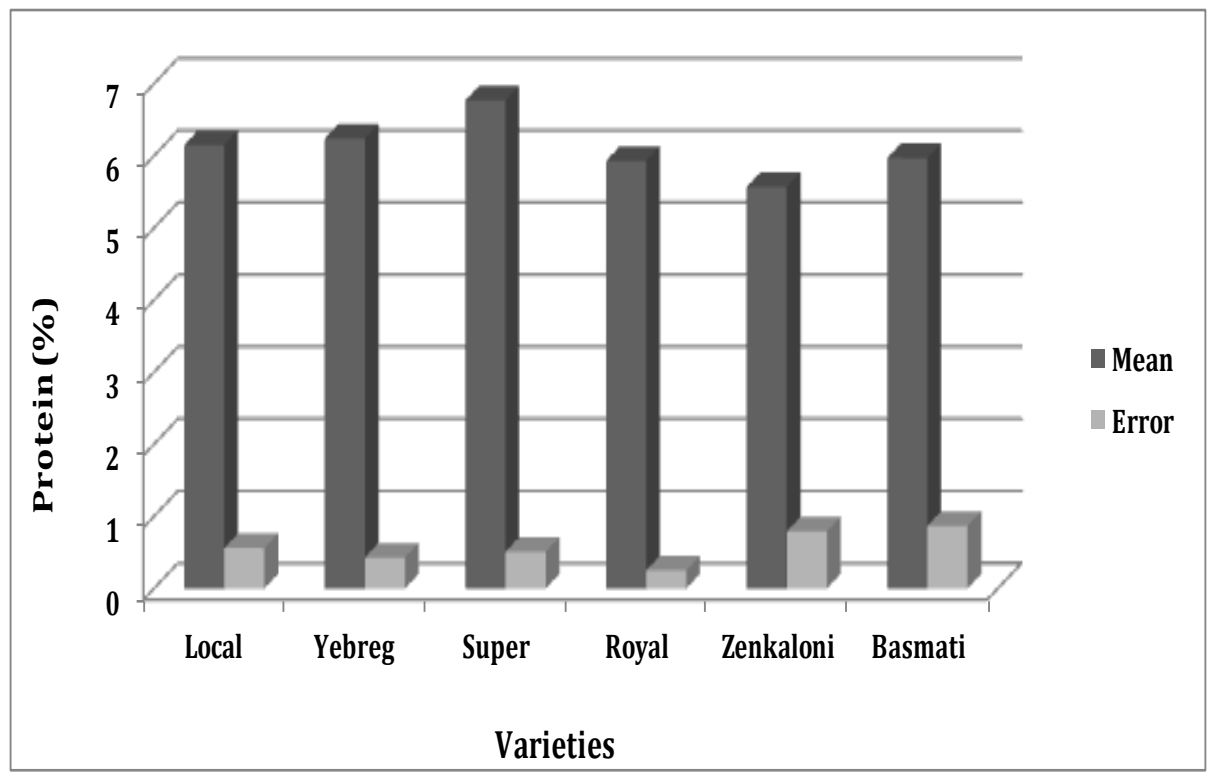

Figure 3: Distribution of protein in rice varieties. 


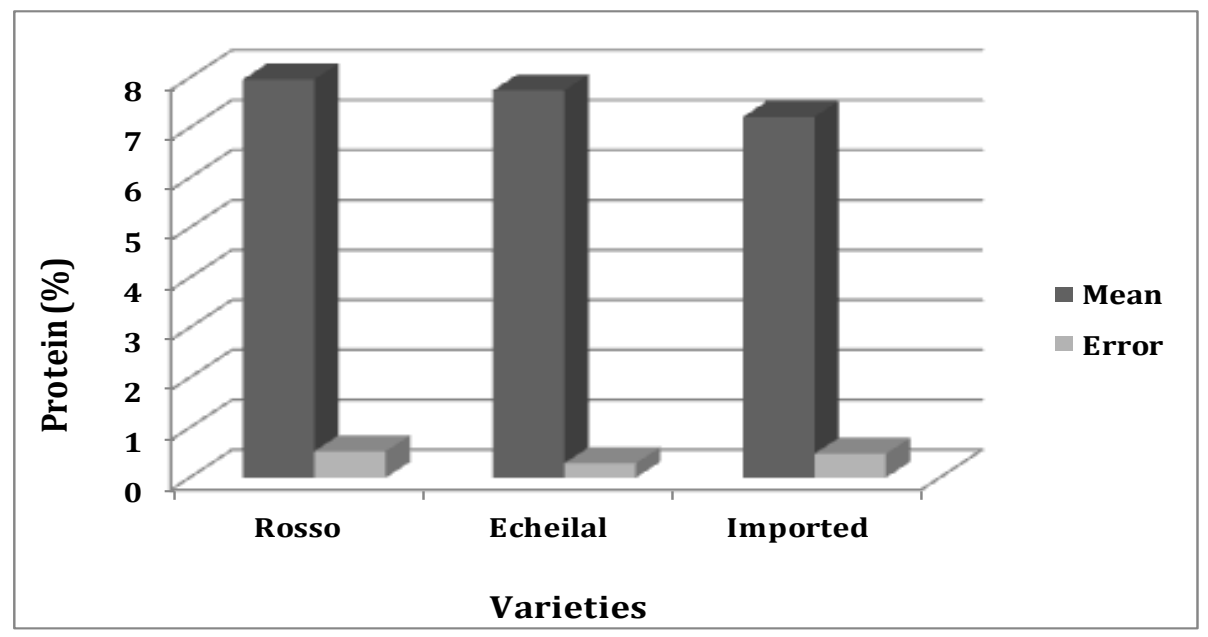

Figure 4: Distribution of protein in wheat varieties.

Table 1: Mineral composition of some rice and wheat varieties.

\begin{tabular}{llllll}
\hline & Varieties & $\mathbf{N a}\left(\mathbf{m g ~ k} \mathbf{~ g}^{-\mathbf{1}}\right)$ & $\mathbf{K}\left(\mathbf{m g ~ k g}^{-\mathbf{1}}\right)$ & $\mathbf{C a}\left(\mathbf{m g ~ k g}^{-\mathbf{1}}\right)$ & $\mathbf{F e}\left(\mathbf{m g ~ k g}^{-\mathbf{1}}\right)$ \\
\hline \multirow{4}{*}{ Rice } & Local & $106 \pm 3.55$ & $345 \pm 3.74$ & $45 \pm 2.16$ & $19.9 \pm 0.82$ \\
& Yebreg & $106 \pm 1.41$ & $291 \pm 1.63$ & $47 \pm 2.94$ & $4 \pm 0.35$ \\
& Super & $119 \pm 2.05$ & $384 \pm 3.84$ & $41 \pm 1.42$ & $8.7 \pm 0.37$ \\
& Royal & $80 \pm 3.77$ & $306 \pm 3.55$ & $34 \pm 1.63$ & $16 \pm 0.35$ \\
& Zenkaloni & $107 \pm 3.74$ & $478 \pm 3.55$ & $46 \pm 0.83$ & $0.5 \pm 0.01$ \\
& Basmati & $92 \pm 2.94$ & $448 \pm 3.26$ & $29 \pm 1.29$ & $13 \pm 0.35$ \\
& Rosso & $105 \pm 2.16$ & $1030 \pm 3.74$ & $9.36 \pm 0.82$ & $27.9 \pm 0.86$ \\
& Echeilal & $134 \pm 1.63$ & $1210 \pm 4.32$ & $15.5 \pm 0.45$ & $33.8 \pm 1.14$ \\
& imported & $107 \pm 2.16$ & $1040 \pm 3.55$ & $36 \pm 0.57$ & $7 \pm 0.14$ \\
\hline
\end{tabular}

Table 2: Heavy metals of some corn varieties.

\begin{tabular}{llll}
\hline & Varieties & $\mathbf{P b}\left(\mu \mathrm{g} \mathrm{Kg}^{-1}\right)$ & $\mathbf{C d}\left(\mu \mathrm{g} \mathrm{Kg}^{-1}\right)$ \\
\hline & Local & $70 \pm 2.16$ & $40 \pm 0.81$ \\
Yebreg & $10 \pm 0.85$ & $70 \pm 1.41$ \\
& Super & $60 \pm 0.97$ & $30 \pm 1.04$ \\
& Royal & $110 \pm 0.72$ & $100 \pm 1.63$ \\
& Zenkaloni & $70 \pm 0.21$ & $40 \pm 1.04$ \\
Wheat & Basmati & $50 \pm 0.92$ & $60 \pm 0.81$ \\
& Rosso & $200 \pm 1.79$ & $100 \pm 0.92$ \\
& Echeilal & $100 \pm 0.98$ & $100 \pm 0.97$ \\
& imported & $40 \pm 1.01$ & $200 \pm 1.40$ \\
\hline
\end{tabular}




\section{DISCUSSION}

\section{Moisture content}

Moisture is also an indicator of grain storability and can predict profit margins in milling. The moisture content of the rice varieties ranged between 6.95 to $8.66 \%$ (Figure 1). The moisture content in this study is low than the reported by some authors (Thomas et al., 2013) .for other rice samples and varieties. The moisture content of the wheat varieties ranged between 5.56 to $7.07 \%$ (Figure 2). The moisture levels of all wheat are lower than the reported by (El khayat et al., 2016).

\section{Protein content}

Protein content influences the nutritional quality of rice. The protein content of the tested varieties ranged from 5.57 to $6.78 \%$ with the highest and lowest found in Super and Zenkaloni rice respectively (Figure $3)$. The protein content was found slightly similar to the reported by (Kang et al., 2011). Protein content in wheat varieties varied between 7.22 and $7.98 \%$. Wheat variety Rosso (7.98\%) followed by Echeilal (7.55\%) showed more protein content than imported wheat variety $(7.22 \%)$ (Figure 4$)$.

\section{Mineral content}

Minerals are well known essential nutrients and provide a vital role in the effective functioning of the body activity. $\mathrm{Na}$ content of the rice samples ranged from 80 to $119 \mathrm{mg} \mathrm{kg}^{-1}$ with the lowest and highest calcium content found in Royal and Super rice respectively (Table 1). For $\mathrm{Na}$, the highest concentration was $134 \mathrm{mg} \mathrm{kg}^{-1}$ and found in Echeilal wheat. The lowest Na concentration was $105 \mathrm{mg} \mathrm{kg}^{-1}$ and found in Rosso wheat (Table 1). $\mathrm{K}$ was the most abundant mineral component in all varieties rice with a range of 291-478 $\mathrm{mg} \mathrm{kg}^{-1}$ (Table 1). $\mathrm{K}$ content in all varieties rice is absolutely within the range of values reported by another authors (Kang et $\mathrm{al}, 2011)$. The highest $\mathrm{K}$ concentration was $1210 \mathrm{mg} \mathrm{kg}^{-1}$ followed by $1040 \mathrm{mg} \mathrm{kg}^{-1}$ in Echeilal and imported wheat, respectively (Table 1). Calcium is an important mineral element used for human consumption, especially for bone development. Ca content of the samples ranged from 29 to $47 \mathrm{mg} \mathrm{kg}^{-1}$ with the lowest and highest calcium content found in Basmati and Yebreg rice respectively (Table 1). The Ca content of the samples was lower than reported by (Liang, 2007). The highest $\mathrm{Ca}$ concentration of $36 \mathrm{mg} \mathrm{kg}^{-1}$ and $15.5 \mathrm{mg} \mathrm{kg}^{-1}$ was found in imported wheat and Echeilal wheat respectively, while the concentration in Rosso wheat (6.4 $\mathrm{mg} \mathrm{kg}^{-1}$ ) was the lowest (Table 1). Fe is essential for the formation of haemoglobin of red blood cells. The $\mathrm{Fe}$ content of the tested varieties ranged from 0.5 to $19.9 \mathrm{mg} \mathrm{kg}^{-1}$ with the lowest and highest obtained from Zenkaloni and Local rice respectively (Table 1). Fe content in local is similar than that found by (Verm \& Srivastava, 2017). The highest concentration of $\mathrm{Fe}$ was $33.8 \mathrm{mg} \mathrm{kg}^{-1}$ and was found in Echeilal wheat followed by Rosso wheat with a concentration of $27.9 \mathrm{mg} \mathrm{kg}^{-1}$. The lowest concentration was found in Echeilal wheat with a concentration of $6.8 \mathrm{mg}$ $\mathrm{kg}^{-1}$ (Table 1).

The mineral content of Zenkaloni was found to be significantly higher than the other rice varieties while the mineral content of Echeilal was found to be significantly higher than the other wheat varieties. We can also notice that the mineral content of the six rice varieties can be classified as follows: Zenkaloni> Basmati> Super $>$ Local $>$ Royal > Yebreg while that the mineral content of the three wheat varieties can be classified as follows: Echeilal > Imported> Rosso.

\section{Heavy metals}

Heavy metals such as $\mathrm{Pb}$ and $\mathrm{Cd}$ are toxic elements that are omnipresent at low concentrations in the environment. The $\mathrm{Pb}$ content of the tested rice varieties ranged from 110 to $10 \mu \mathrm{g} \mathrm{kg}^{-1}$ with the highest and lowest found in Royal and Yebreg rice, respectively (Table 2). The highest concentration of $\mathrm{Pb}$ was $200 \mu \mathrm{g} \mathrm{kg}^{-1}$ and was found in Rosso wheat followed by Echeilal wheat with a concentration of $100 \mu \mathrm{g} \mathrm{kg}$. The lowest concentration was found in imported wheat with a concentration of $40 \mu \mathrm{g} \mathrm{kg}^{-1}$ (Table 2). The $\mathrm{Pb}$ contents recorded in this study are 
very low than the maximum limit proposed by (Codex STAN, 2009). The highest Cd concentration was $100 \mu \mathrm{g} \mathrm{kg}^{-1}$ in Royal followed by $70 \mu \mathrm{g} \mathrm{kg}^{-1}$ in Yebreg rice, respectively (Table 2). The highest $\mathrm{Cd}$ concentration of $200 \mu \mathrm{g} \mathrm{kg}^{-1}$ was found in imported wheat, while the concentrations in Echeilal and Rosso wheat $\left(100 \mu \mathrm{g} \mathrm{kg}^{-1}\right)$ were the lowest (Table 2). The $\mathrm{Cd}$ contents recorded in this study are very low than the maximum limit proposed by Codex (Codex STAN, 2009).

\section{Conclusion}

This is the first scientific report on the physicochemical parameters of the marketed rice and wheat in Mauritania. The results could serve as baseline information. The physicochemical characteristics of the six rice and three wheat varieties tested are quite good. The moisture, the protein, the minerals and heavy metals were all within acceptable levels. Complementary studies such as the characterization of the bioactive molecules and assessment of organic micropollutants such as the pesticides and aflatoxins especially in rice and wheat must be realized.

\section{REFERENCES}

Codex STAN. 2009. Norme générale pour les contaminants et les toxines présents dans les produits de consommation humaine et animale. Codex STAN.

El-Khayat G, Samaan J, Manthey F, Fuller M, Brennan C. 2016. Durum wheat quality I: some physical and chemical characteristics of Syrian durum wheat genotypes. International Journal of Food Science and Technology, 41(S2): 22-29. DOI: $10.1111 / \mathrm{j} .1365-$ 2621.2006.01245.x

FAOSTAT. 2017. United Nations Food and Agriculture Organization. FAOSTAT http://faostat.fao.org.
Thomas R, Wan-Nadiah WA, Rajeev Bhat. 2013. Physiochemical properties, proximate composition, and cooking qualities of locally grown and imported rice varieties marketed in Penang, Malaysia. Int. Food Res. J., 20(3): 13451351.

Uthayakumaran S, Wrigley C. 2017. Wheat: grain-quality characteristics and management of quality requirements. In Cereal Grains: Assessing and Managing Quality. Woodhead Publishing Limited; 59-111.

Kang M-Y, Kim J-H, Rico CW, Namet S-H. 2011. Comparative Study on the Physicochemical Characteristics of Black Rice Varieties. International Journal of Food Properties, 146: 12411254. DOI: $\quad 10.1080 \quad$ / 10942911003637350

Liang.2007. Iron, Zinc and Phytic Acid in Rice from China: Wet and Dry Processing towards Improved Mineral Bioavailability.

Mourouti N, Kontogianni MD, Papavagelis C, Psaltopoulou T, Kapetanstrataki MG, Plytzanopoulou P, Vassilakou T, Malamos N, Linos A, Panagiotakos DB. 2016. Whole Grain Consumption and Breast Cancer: A Case-Control Study in Women. J. Am. Coll. Nutr., 35: 143-149. DOI: 10.1080 / 07315724.20.9.963899

Verma DK, Srivastav PP. 2017. Proximate composition, mineral content and fatty acids analyses of aromatic and nonaromatic Indian rice. Rice Science, 24(1): 21-31. DOI: https://doi.org/10.1016/j.rsci.2016.05.00 5

Yadav RB, Khatkar BS, Yadav BS. 2007. Morphological, physicochemical and cooking properties of some Indian rice (Oryza sativa L.) cultivars. J. Agric. Technol., 3(2): 203-210. 